\title{
Establishment and spread of Rhizophagus grandis Gyll (Coleoptera: Rhizophagidae) 6 years after release in the Forêt domaniale du Mézenc (France) ${ }^{\dagger}$
}

\author{
A van Averbeke, JC Grégoire * \\ Laboratoire de biologie animale et cellulaire, $C P$ 160/12, université libre de Bruxelles, \\ 50, av FD-Roosevelt, B-1050 Brussels, Belgium
}

(Received 11 March 1994; accepted 9 August 1994)

\begin{abstract}
Summary - Sampling was carried out in August 1993 in a Norway spruce stand (Forêt domaniale du Mézenc, Haute-Loire, France) heavily infested by the bark beetle, Dendroctonus micans, and where the predatory beetle, Rhizophagus grandis, had been released in 1987. Three circular plots, $20 \mathrm{~m}$ in diameter, were marked out in the vicinity of the release area, and all trees within were examined. All $D$ micans brood chambers below $2 \mathrm{~m}$ were opened and their contents analysed. Three similar plots were created $800 \mathrm{~m}$ or so away from the release area. In addition, a number of brood chambers were sampled at the release area's limit, and at distances of about $800-900 \mathrm{~m}$ and $1090 \mathrm{~m}$. There was a significant inverse relationship between local tree density and proportion of attacked trees $\left(r^{2}=0.91 ; p<0.01\right)$. However, there was a significant direct relationship between local tree density and absolute numbers of attacked trees $\left(r^{2}=0.92 ; p<0.01\right)$. Adults and larvae of the predator were found along the whole transect. Only prey brood chambers containing 5 th instar larvae or older stages were colonised by $R$ grandis. The $R$ grandis/D micans ratio, counting all individuals in each brood chamber, significantly decreased as distance increased $\left(r^{2}=0.18 ; p<0.05\right)$. These findings suggest an effective but slow spread in predators released from a limited spot in a densely attacked stand. They fit well with earlier information from other release sites in the Massif Central.
\end{abstract}

Rhizophagus grandis / Dendroctonus micans / biological control / dispersal / Scolytidae / Rhizophagidae

Résumé - Établissement et dispersion de Rhizophagus grandis (Coleoptera: Rhizophagidae) 6 ans après lâcher dans la forêt domaniale du Mézenc (Haute-Loire). Des échantillonnages ont été effectués en août 1993 dans un peuplement d'épicéas communs (forêt domaniale du Mézenc, HauteLoire), fortement infesté par le scolytide Dendroctonus micans, le long d'un transect de $1100 \mathrm{~m}$ de longueur débutant au niveau d'une parcelle où le coléoptère prédateur Rhizophagus grandis avait été lâché en 1987 (fig 1). Trois placettes de $10 \mathrm{~m}$ de rayon ont été délimitées au voisinage immédiat de la par-

* Correspondence and reprints. Senior Research Associate at the Fonds national belge de la recherche scientifique.

† This work is dedicated to the late CJ King. 
celle de lâcher, et tous les arbres qu'elles contenaient ont été examinés. Les systèmes de D micans en dessous de $2 \mathrm{~m}$ ont été ouverts et inventoriés. Trois autres placettes circulaires ont été examinées à environ $800 \mathrm{~m}$ de la parcelle de lâcher. De plus, un certain nombre d'attaques supplémentaires ont été analysées, à proximité immédiate de la zone de lâcher, à 800-900 m et à $1090 \mathrm{~m}$. La proportion d'arbres attaqués décroit de manière hautement significative $\left(\mathrm{r}^{2}=0,91 ; \mathrm{P}<0,01\right)$ en fonction de la densité locale d'arbres. Cependant, si l'on considère le nombre absolu d'arbres attaqués, il croit significativement $\left(\mathrm{r}^{2}=0,92 ; \mathrm{P}<0,01\right)$ avec la densité (fig 2). Ces derniers résultats, qui rejoignent d'autres données extraites de la littérature (table II), démentent une opinion fréquente selon laquelle les risques liés à $\mathrm{D}$ micans sont plus élevés à basse densité. Le nombre de $\mathrm{D}$ micans (laves, nymphes et adultes) comptés dans chaque système intra-cortical croit, bien que de manière non statistiquement significative, lorsque l'on s'éloigne de la zone de lâcher. Inversement, le nombre de R grandis décroît (fig 3). Des adultes et des larves du prédateur furent découverts tout le long du transect. Seuls les systèmes intra-corticaux contenant des larves du $5^{\circ}$ stade de $\mathrm{D}$ micans ou des stades plus âgés étaient colonisés par le prédacteur. Le rapport $\mathrm{R}$ grandis/D micans, obtenu à partir d'un décompte de tous les individus dans chaque système, décroît de manière significative $\left(\mathrm{r}^{2}=0,18 ; \mathrm{P}<0,05\right)$ avec la distance (fig 4). Ces données suggèrent que le prédateur se disperse effectivement mais avec lenteur lorsqu'il est libéré de manière ponctuelle dans un peuplement très infesté.

Rhizophagus grandis / Dendroctonus micans / lutte biologique / dispersion / ennemis naturels / Scolytidae / Rhizophagidae

\section{INTRODUCTION}

The bark beetle Dendroctonus micans, a pest of spruce, has been continuously spreading in France in the Massif Central area since the early seventies (Carle et al, 1979; Grégoire, 1988). Control methods include sanitary thinning and clear-felling, and biological control using the predatory beetle, Rhizophagus grandis (Grégoire et al, 1984, 1985, 1986; Monestier and Roque, $1990)$. $R$ grandis is mass-reared in insectaries, and released in the infested stands (Grégoire et al, 1984, 1985, 1986; King and Evans, 1984) where it rapidly discovers and colonises $D$ micans brood chambers. Several studies (Tvaradze, 1977; Grégoire et al, 1985, 1989; Evans and King, 1989; Fielding et al, 1991) have already shown that this colonisation process occurs at the rate of about $200 \mathrm{~m} /$ year, with exceptional movements of $1 \mathrm{~km}$ or more. These studies, however, have been based mostly on 'predator's presence versus absence' criteria, using each brood chamber as a single counting unit. Moreover, they have not been designed to monitor the gradual spread of $R$ grandis into a new area but, instead, were aimed at describing an instantaneous situation at a given time after release. The present work attempts to identify other criteria, such as population changes within the brood chambers (numbers of predators or prey and predator/prey ratios), or proportions of colonised broods, which could be used to measure range expansion in the predator.

\section{MATERIALS AND METHODS}

\section{The stand}

The study was made in August 1993 in a stand near the village of Les Estables on the slopes of Mount Alambre and Mount Costebelle (HauteLoire, France). It is stocked with pure, even-aged Norway spruce on average 90 years old, on a $7^{\circ}$ slope facing north-east, at an altitude of $1500 \mathrm{~m}$. Tree density varies from 500 to 775 stems/ha. The stand contains a permanent plot of 352 trees created in 1977 by the Station de zoologie forestière d'Avignon of the Institut national de la recherche agronomique (Vouland, 1991). Attacks by $D$ micans were first recorded there in 1983 . A total of $2000 \mathrm{~A}$ grandis were released on this plot in 1987. 


\section{Transect and sampling plots}

The transect started at the SE edge of the INRA permanent plot (fig 1). It followed a SSE direction for about $1100 \mathrm{~m}$, until younger spruce plantations were met. The topography of the stand might have allowed a second transect of the same size at $180^{\circ}$ of the first one, but time constraints made this impracticable.

Three circular plots, $20 \mathrm{~m}$ in diameter, were created at the start of the transect. All trees within each plot were examined; $D$ micans brood chambers below $2 \mathrm{~m}$ were carefully opened and their contents were collected for counting all stages of both species in the laboratory. Three additional plots were created at $700-800 \mathrm{~m}$ from the transect's start. This wide interval was kept between the 2 groups of plots in order to make as clear as possible any existing population gradient due to diffusion of the predators from the release plot. Details of the plots are given in table I.

\section{Additional sampling}

In order to obtain additional information on the effects of distance from the release plot on attack rates, colonisation rates and demographic conditions within the galleries, a number of additional trees were sampled at the vicinity of the circular plots and also at the transect's end, about 1090 $\mathrm{m}$ from the release plot. Only mature brood cham-

Table I. Characteristics of the sampling plots.

$\begin{array}{cccc}\text { Plot } & \begin{array}{c}\text { Total number } \\ \text { of trees }\end{array} & \begin{array}{c}\text { Density } \\ \text { (trees/ha) }\end{array} & \begin{array}{c}\text { Distance from } \\ \text { start }(\mathrm{m})\end{array} \\ & & & \\ \text { A } & 8 & 255 & 6 \\ \text { B } & 18 & 573 & 22 \\ \text { C } & 21 & 668 & 42 \\ \text { D } & 21 & 668 & 814 \\ \text { E } & 23 & 732 & 800 \\ \text { F } & 29 & 923 & 718\end{array}$

bers (containing 5 th instar larvae and older stages) were sampled.

\section{RESULTS}

\section{Proportion of trees attacked}

The proportions of trees attacked varied from 47.8 to $75 \%$. They were not significantly influenced by distance from the release plot $\left(r^{2}=0.52 ; p>0.05 ; 4 d f\right.$, analysis after arcsine transformation of the data: $y=2$ arc$\sin \sqrt{ }(x)$. Similarly, absolute numbers of attacked trees were not influenced by distance $\left(r^{2}=0.29 ; p>0.05 ; 4 d f\right)$.

A much better relationship was obtained by plotting proportions of attacked trees (after arcsine transformation; $r^{2}=0.92 ; p<0.01$; $4 d f)$ or numbers of attacked trees $\left(r^{2}=0.92\right.$; $P<0.01 ; 4 d f$ ) against stand density (fig 2).

\section{Population size within the galleries along the transect}

The numbers of $D$ micans and $R$ grandis of all stages found per brood chamber did not vary significantly as distance from the release plot increased ( $D$ micans: $r^{2}=0.09$; $p>0.05 ; 31 d f, R$ grandis: $r^{2}=0.07 ; p>$ $0.05 ; 31 d f$, fig 3 ).

\section{Dominant stages of $\mathrm{D}$ micans}

Overall, 57 brood chambers were examined in the 6 circular plots. All developmental stages were represented. Attributing the brood chambers to the oldest stage present, they distributed themselves as follows: egggalleries, $9.2 \%$; 1st-2nd instar larvae, 3.4\%; 3rd-4th instar larvae; $0.2 \%$; 5 th instar larvae, $36,4 \%$; pupae, $41.0 \%$; young, preemergent adults, $9.9 \%$. $R$ grandis was only found in brood systems containing at least the 5th instar larvae. 


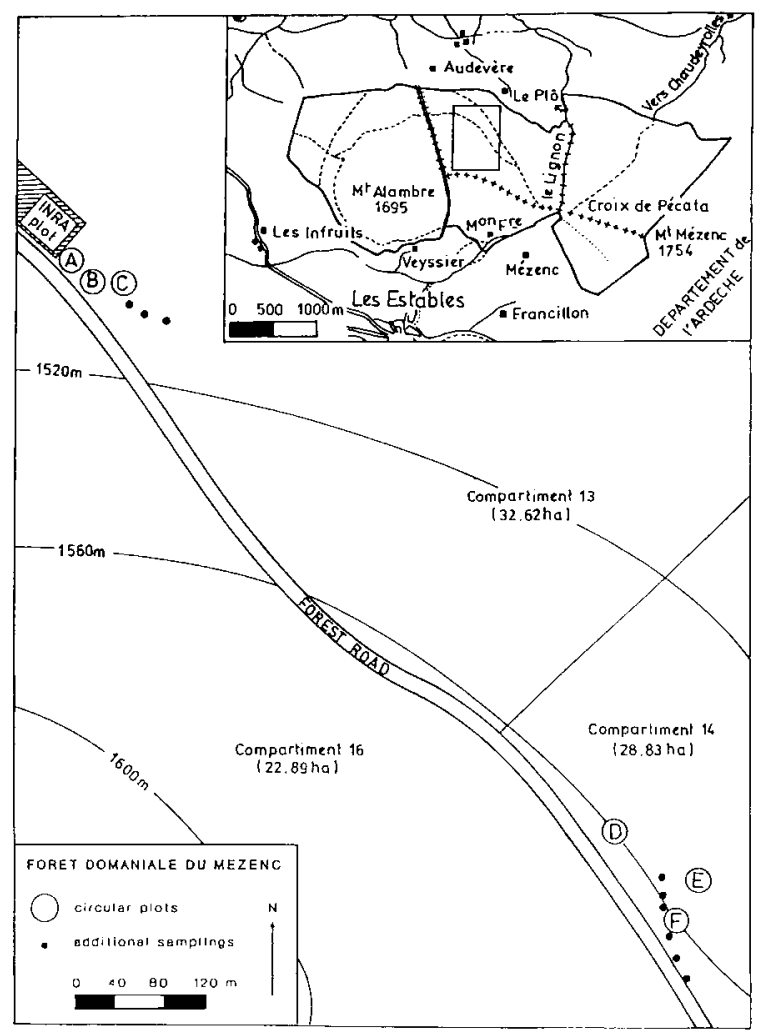

Fig 1. Forêt domaniale du Mézenc. Map of the sampling plots on Mount Alambre.

\section{Colonisation of D micans brood chambers by $\mathrm{R}$ grandis}

In the vicinity $(40 \mathrm{~m})$ of the release area (plots $A, B, C$ ), $27.8 \%$ of all brood chambers opened were found to contain $R$ grandis. At about $800 \mathrm{~m}$ (plots $\mathrm{D}, \mathrm{E}, \mathrm{F}$ ), only $5.1 \%$ of the brood chambers were colonised by the predators. Considering only the brood systems containing 5th instar larvae of the prey or older stages, $80 \%$ of the broods were colonised at $40 \mathrm{~m}$ from the release area (plots $A, B, C$ and additional sampling), and $54.2 \%$ at $800 \mathrm{~m}$ (plots D, $E, F$ and additional sampling). However, there was no linear relationship between colonisation rates (arcsine transformation) and distance from the release area $\left(r^{2}=\right.$ 0.09 ; $p>0.05$; fig 4).

Within each brood chamber (all brood chambers opened were considered here), the ratio between the numbers of $R$ grandis and $D$ micans (individuals of all stages found in a chamber) significantly decreased with the distance from the release plot (fig $5 ; r^{2}=0.18 ; 0.01<p<0.05 ; 31 d f$ ).

\section{Local attack density and colonisation by $R$ grandis}

Colonisation rates were measured in each of the 6 circular plots, as ratios between num- 


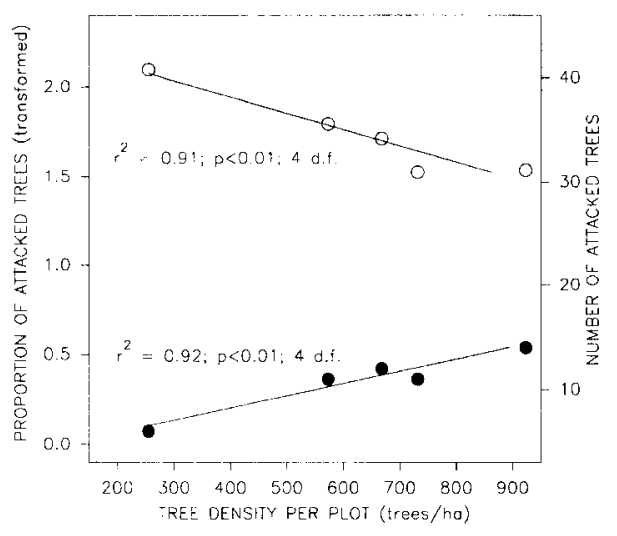

Fig 2. Numbers $(\bullet)$ and proportions $(\mathrm{O})$ (after arcsine transformation) of attacked trees in the sampling plots, plotted against plot density.

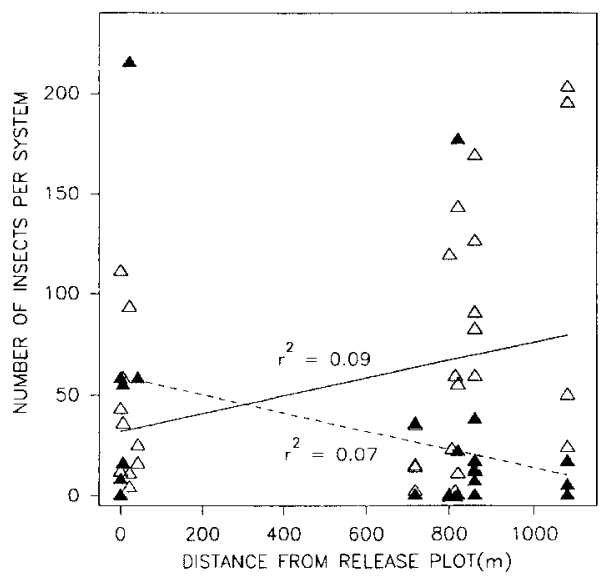

Fig 3. Number of $D$ micans $(\Delta)$ and $R$ grandis ( $(\mathbf{\Delta})$ individuals per brood chamber along the transect.

bers of broods colonised by $R$ grandis and total numbers of broods. There was no correlation between colonisation rate by $R$ grandis (arcsine transformation) and tree density in each plot $\left(r^{2}=0.56 ; p>0.05 ; 4 d f\right)$. Similarly, we observed no link between proportions of colonised broods (arcsine transformation) and numbers of attacked trees ( $r$ $2=0.57 ; p>0.05 ; 4 d f$, or between propor-

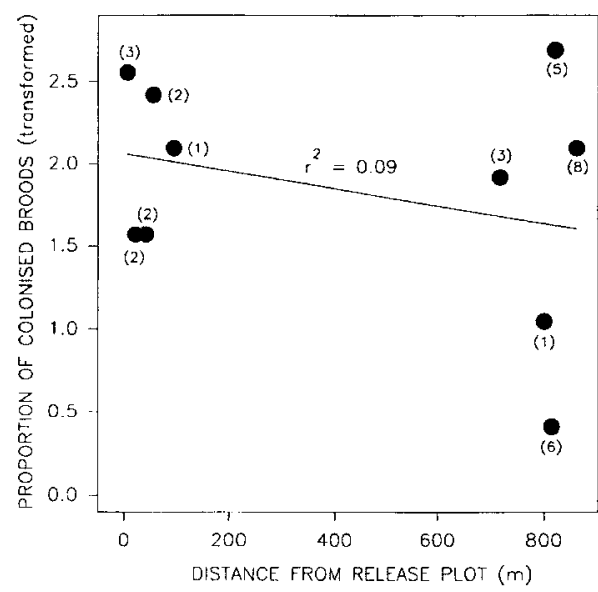

Fig 4. Proportions (after arcsine transformation) of $D$ micans brood chambers colonised by $R$ grandis along the transect. Numbers into brackets represent the numbers of broods sampled at each point.

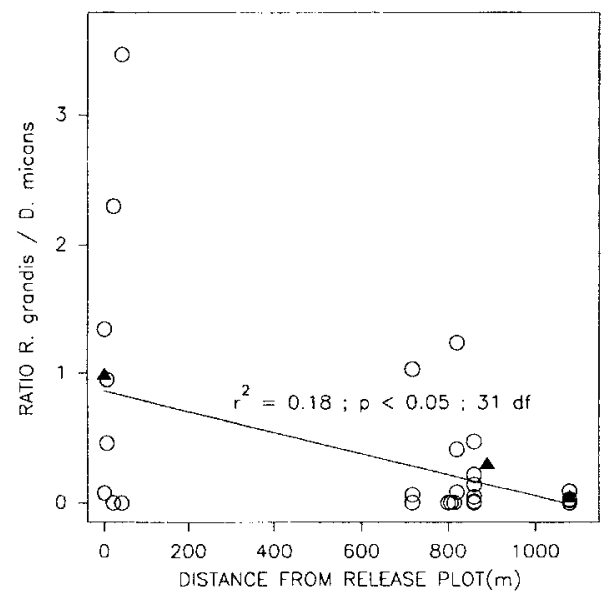

Fig 5. Numerical relationships between $R$ grandis and $D$ micans within the brood chambers along the transect. Individual ratios: $O$; total ratio/plot: $A$

tions of colonised broods (arcsine transformation) and total numbers of attacks per plot $\left(r^{2}=0.44 ; p>0.05 ; 4 \mathrm{df}\right)$. On the other hand, there was a significant, positive relationship $\left(r^{2}=0.70 ; 0.01<p<0.05 ; 4 d f\right)$ between 
brood chamber (all developmental stages of $D$ micans), colonisation rate by $R$ grandis (arcsine transformation), and proportions of attacked trees (all developmental stages of $D$ micans; arcsine transformation).

\section{DISCUSSION}

From our sampling, $47.8 \%$ of trees were attacked in the vicinity of the $R$ grandis release area, a much greater figure than the $11.5 \%$ recorded there in 1987 (G Vouland, personal communication) when the predators were released. This is not alarming per se and could merely reflect the fact that the first predators released were diluted among a high number of attacked trees. Tvaradze (1977) reported that in the Georgian Republic immediate success (in terms of reduced damage) following releases of $R$ grandis was observed only when the proportion of attacked trees was $3 \%$ or less. In most cases, however, complete control of $D$ micans took $7-10$ years in the same region (Zharkhov, personal communication in Evans and King, 1989). Similar trends have also been observed in France, in stands previously treated with $R$ grandis, further south in the Massif central (Forêt domaniale de l'Aigoual, Massif du Lingas). For example, 2 infested stands (numbers 5019 and 5020) were treated in 1984. Five years later, in 1989 , the attack rates were $53.6 \%$ and $56.2 \%$ respectively. In 1993,9 years after the releases, we found only 8.6 and $8.9 \%$ respectively of trees attacked (unpublished data). The data presented here illustrate the fact that, although damage is still increasing, less directly perceptible changes occur within the stand as a result of the release. $R$ grandis is definitely colonising the stand, although slowly, and the first signs of this process can already be observed within the galeries.

The observed percentages of attacked trees decreased with the samples' distance from the release plot. This relationship was not statistically significant however, and there is thus no sign of local decrease in numbers of attacked trees as a result of a high density of predators. Moreover, the absolute numbers of attacked trees increased, although not significantly. We believe that what really matters here is local tree density and not predator abundance, as there was a highly significant inverse relationship between local tree densities and proportions of attacked stems. This relationship has already been observed by other authors (Gøhrn et al, 1954; Shavliashvili and Zharkhov, 1985), and interpreted as a lower susceptibility of dense stands to $D$ micans. However, our own data show that the absolute numbers of attacked trees per plot increased highly significantly with tree density. Analysing other authors' data (Granet and Perrot, 1977; Bejer, 1984), we found results similar to our own (table II). Interestingly, Bejer's data in table II are the same as those used by Gøhrn et al (1954).

After 6 years, $R$ grandis is present at least at $1100 \mathrm{~m}$ from the release plot. This is consistent with previously published reports of a yearly expansion of about $200 \mathrm{~m}$ (Tvaradze, 1977; Grégoire et al, 1985, 1989; Evans and King, 1989; Fielding et al, 1991). Brood colonisation varied along the transect, with a maximum near to the release area where $80 \%$ of the older broods were colonised. This figure is comparable to colonisation levels observed in endemic $D$ micans/R grandis populations (Grégoire, 1988). Colonisation rates decreased with increasing distance from the release area. This relationship was too diffuse however to be used accurately for measuring predator establishment, and, on the other hand, predator impact is also dependent upon the amount of time spent in a brood chamber. We therefore attempted to use other critiria, ie prey and predator numbers per brood along the transect. Although these increased and decreased respectively with increasing 
Table II. Tree density, proportions of attacked trees and absolute numbers of attacked trees (data from the literature).

$\begin{array}{lcc}\text { Density } & \text { Proportion of } & \text { No of attacked } \\ \text { (trees/ha) } & \text { attacked trees (\%) } & \text { trees }\end{array}$

Granet and Perrot (1977)

$\begin{array}{rll}1080 & 40 & 432 \text { * } \\ 680 & 46 & 312^{*} \\ 590 & 46 & 271^{*} \\ 310 & 88 & 272 \text { * }\end{array}$

Bejer (1984) ${ }^{1}$ and personal communication 2

$\begin{array}{rll}2300^{2} & 18^{*} & 4151 \\ 1000^{2} & 68^{*} & 6751 \\ 600^{2} & 89^{*} & 5351 \\ 400^{2} & 93^{*} & 370^{1}\end{array}$

* Our calculation.

distances from the release area, these changes were not significant when submitted to a linear regression analysis. However, the $R$ grandis/D micans ratios significantly varied along the transect. This value at a given distance from the release area may result from the combined effects of several factors: proportion of broods colonised, duration of $R$ grandis establishment, oviposition and prey consumption by $R$ grandis. Further assessments should confirm whether it provides a good measurement criterion for measuring the predator's impact.

Only brood systems with 5 th instar larvae or older stages were found to contain $R$ grandis. This is by no means a general rule, as predators have been regularly reported under other circumstances in younger prey brood systems, although colonisation rates were lower than with more mature broods (Grégoire, 1988). The scarcity of younger broods in our sampling, combined with their lower probability to be colonised are the most likely reasons for $R$ grandis' exclusive choice of older broods in our samples.
Proportions of broods colonised by $R$ grandis were independent of densities of attacked trees and total numbers of attack per plot, suggesting that, at this stage of stand colonisation by the predators, there is no density-dependent numerical response of $R$ grandis to its prey. There was, however, a significant, positive relationship between proportions of colonised broods and proportions of trees attacked by $D$ micans in each plot, but this relationship probably has little biological meaning, as tree density widely varied between plots (see table I), so that proportions of attacked trees per plot are a poorer image of plot infestation level than are numbers of attacked trees (see discussion above, and fig 2). The literature provides some information suggesting direct density-dependence. On average, $60 \%$ of the brood chambers are colonised in Belgium at low prey density (Grégoire, 1988), whilst up to $78 \%$ of the broods can be colonised during outbreaks (Tvaradze, 1977). This apparent divergence with our present data may result from the fact that, in the Forêt du Mézenc, $R$ grandis is still invading the stand, and that its spread in space involves most of the population which would otherwise have to face local variations in prey density. Another difference may lie in the scale of observations, ie small plots in the present study versus whole stands in the literature.

To date, the biological control of $D$ micans is still rather an empirical technique. Release rates, for instance, are established according to external priorities instead of scientific data, ranging from 10-50 pairs/site in the United Kingdom (King and Evans, 1984) to 50-1 000 pairs/site in France (Grégoire et al, 1989). Furthermore, time allowance for success is still unpredictable, and what really happens within this interval is not known. "Success" has yet to be quantitatively defined. Practice teaches us that, several years after a release, rates of infestation by $D$ micans will always fall down to, and remain 
at, a harmless low level below $5-10 \%$ of attacked trees, and that $60-80 \%$ of the broods will be colonised by $R$ grandis. However, we are still unable to establish the maximal threshold of attack by $D$ micans and the minimal rate of brood colonisation by $R$ grandis that characterise successful control in a stand. For this, we still need to understand the processes occurring at the brood chamber level between the moment of predator release and total control. The aim of the present study was to contribute to this approach.

\section{ACKNOWLEDGMENTS}

We thank S Aubry, D Gillet and J Duny (Office national des forêts, Service départemental de la Haute-Loire) for help, information and support. We are also very grateful to $T$ Wyatt (Oxford University) for his critical reading of the manuscript, and to an unknown reviewer for very helpful remarks. JCG acknowledges financial support from the Belgian Funds for Scientific Research.

\section{REFERENCES}

Bejer B (1984) Dendroctonus micans in Denmark. In: Proc EEC Sem Biol Control Bark Beetles (JC Grégoire, JM Pasteels, eds), Brussels, 2-19

Carle P, Granet AM, Perrot JP (1979) Contribution à l'étude de la dispersion et de l'agressivité chez Dendroctonus micans Kug en France. Bull Soc Entomol Suisse 52, 185-196

Evans HF, King CJ (1989) Biological control of Dendroctonus micans (Coleoptera: Scolytidae): British experience of rearing and release of Rhizophagus grandis (Coleoptera: Rhizophagidae). In: The Potential for Biological Control of Dendroctonus and lps Bark Beetles (D Kulhary, MC Miller, eds), The Stephen Austin University Press, Nagocdoches, USA, 109-128

Fielding NJ, O'Keefe T, King CJ (1991) Dispersal and host-finding capability of the predatory beetle $R$ hizopagus grandis Gyll (Col Rhizophagidae). J Appl Entomol 112, 89-98

Gøhrn V, Henriksen AM, Bejer-Petersen B (1954) lagttagelser over Hylesinus (Dendroctonus micans). Forst Forsogv Danmark 180, 380-433

Granet AM, Perrot JM (1977) Dendroctonus micans Kug dans le sud-est du Massif Central. Aires d'extension et premier essai d'interprétation des dommages. Mémoire de $3^{e}$ année, ENITEF, $125 \mathrm{p}$

Grégoire JC (1988) The greater European spruce beetle. Population Dynamics of Forest Insects (AA Berryman, ed) Plenum, New York, USA, 455-478

Grégoire JC, Baisier M, Merlin J, Naccache Y (1989) Interactions between Dendroctonus micans and $R$ hizophagus granis in the field and laboratory: their application for the biological control of $D$ micans in France. In: The Potential for Biological Control of Dendroctonus and lps Bark Beetles (D Kulhavy, MC Miller, eds), The Stephen Austin University Press, Nagocdoches, USA, 95-108

Grégoire JC, Merlin J, Pasteels JM, Jaffuel R, Vouland G, Schvester D (1984) Mass-rearings and releases of Rhizophagus grandis in Lozère. In: Proc EEC Seminar, Biological Control of Bark Beetles, (Dendroctonus micans) (JC Grégoire, JM Pasteels, eds), Commission of the European Communities, Brussels, 122-128

Grégoire JC, Merlin J, Pasteels JM, Jaffuel R, Vouland G, Schvester D (1985) Biocontrol of Dendroctonus micans by Rhizophagus grandis Gyli (Col Rhizophagidae) in the Massif Central (France). A first appraisal of the mass-rearing and release methods. $Z$ Ang Ent 99, 182-190

Grégoire JC, Merlin J, Jaffuel R, Denis P, Lafont $P$, Schvester D (1986) Élevage à petite et moyenne échelle du prédateur Rhizophagus grandis Gyll en vue de la lutte biologique contre Dendroctonus micans Kug. RFF 38, 457-464

King CJ, Evans HF (1984) The rearing of Rhizophagus grandis and its release against Dendroctonus micans in the United Kingdom. In: Proc EEC Seminar, Biological Control of Bark Beetles (JC Grégoire, JM Pasteels, eds), Commission of the European Communities, Brussels, 87-97

Kobakhidze DN (1965) Some results and prospects of the utilization of beneficial entomophagous insects in the control of insect pests in Georgian SSR (USSR). Entomophaga 10, 323-330

Monestier C, Roque JL (1990) Recherches sur l'Hylésine géant. Arborescence 25, 1-4

Shavliashvili IA, Zharkhov DG (1985) Effects of ecological factors on the interactions between populations of Dendroctonus micans and Ips typographus (Coleoptera: Scolytidae) In: Proc IUFRO Conf The Role of the Host Plant in the Population Dynamics of Forest Insects (L Safranyik, ed), USDA Forest Service and Canadian Forestry Service, Vancouver, BC, Canada, 227-232

Tvaradze MS (1977) Using Rhizophagus grandis to control Dendroctonus micans. Sb Nauchn rab lzuch BE Luboeda Gruzii Tbilissi 3, 56-61 (in Russian)

Vouland G (1991) Le Dendroctone de l'épicéa Dendroctonus micans Kug (Col Scolytidae) dans le Massif Central. PhD thesis, Université d'Aix-Marseille III, France, $126 \mathrm{p}$ 